\title{
Evaluating Students' Cyber Ethics Awareness in a Gender-Segregated Environment Under the Impact of COVID-19 Pandemic
}

\author{
Mahmoud Abou Naaj, Mirna Nachouki \\ Ajman University, University Street, Ajman, UAE
}

\begin{abstract}
Cyber ethics are essential components of information technology. The COVID-19 situation has brought unprecedented challenges to traditional higher education institutions, especially for students using their electronic devices in all their learning activities. This study focused on cyber ethics perceptions among university undergraduates' students during COVID-19 conditions. It aims to analyze the extent to which distinct attributes, such as gender, education level, grades, or Cumulative Grade Point Average (CGPA), and major are related to cyber ethics awareness. An online survey was conducted on a sample of 322 undergraduates studying Information Technology majors and other majors to assess university students' cyber ethics awareness levels at a University in the UAE. The results show that, in general, respondents were aware of cyber ethics. In particular, gender and education level were found to directly affect cyber ethics awareness, while major and grades have no statistically significant effect.
\end{abstract}

Keywords - Academic Ethics, Information Technology, Gender-Segregated Environment, Cyber ethics Awareness Perception

\section{Introduction}

COVID-19 forced higher education institutions to deliver all its courses online, which changed abruptly

DOI: 10.18421/TEM103-31

https://doi.org/10.18421/TEM103-31

Corresponding author: Mahmoud Abou Naaj, Ajman University, University Street, Ajman, UAE. Email: abounaaj@ajman.ac.ae

Received: 09 May 2021.

Revised: 16 July 2021.

Accepted: 23 July 2021.

Published: 27 August 2021.

(c) BY-NC-ND (C) 2021 Mahmoud Abou Naaj \& Mirna Nachouki; published by UIKTEN. This work is licensed under the Creative Commons AttributionNonCommercial-NoDerivs 4.0 License.

The article is published with Open Access at www.temjournal.com the learning environment for both instructors and students. Several challenges emerged for instructors due to this delivery mode, but the most prominent one was the perceived academic misconduct.

The United Arab Emirates (UAE) is considered the most advanced country regarding Information and Communication Technology (ICT) connectivity and digital transformation in the Gulf region specifically and the Middle East in general. People use computers daily in almost all fields, from engineering, education, science, medicine, to commerce, etc. ICT has made education more interactive and has improved the teaching and learning process offered in educational institutions. This stresses the importance of providing adequate cyber ethics education to students in higher education institutes. The UAE has established an excellent and diversified system of higher education in a brief time. There are 74 public and private institutions of higher education in the country. Public universities and some private universities in the United Arab Emirates offer segregated classes, so students who prefer such type choose to complete their education.

COVID-19 forced higher education institutions worldwide to move courses online, the learning environment for instructors and students changed abruptly. A host of challenges for instructors emerged due to the move, but what quickly became one of the most prominent issues was perceived academic misconduct.

During the covid-19 pandemic, students acquired knowledge and progress in their learning by dint of computers as well as internet and technology advancements. Electronic devices, such as the computer and smartphones, have improved students' communication with their instructors using dedicated management learning systems to ask questions, submit HomeWorks, and download course materials. They can also interact with their classmates and friends using social media. These various and frequent utilization of social media and the internet may lead to unethical behaviour while using computer-related devices [1].

The ethical component applied to computers' use is called cyber ethics, which becomes a problem 
nowadays due to Information Technology's advancement. Cyber ethics has attracted massive consideration. Ethical and unethical use of computers has been characterised by copyright infringement, intellectual property violations, plagiarism, digital piracy, crime and abuse, professional practice, and responsibility [2]. Consequently, various research papers presented different definitions of computer misuse. Brey [3] recommended faithfulness to spiritual educations. Al-A'ali [4] debated guidelines related to ethical issues in companies. Foltz et al. [5] came up with understandings related to ethical decision-making. Cavico et al. [2] considered issues associated with the internet's ethical use.

Due to the significance of ethical topics in the ICT, educational institutions have included related courses in several undergraduate and postgraduate courses. Typical engineering, business, and information technology majors include at least a stand-alone computer ethics course in their curricula. Students need to learn what constitutes appropriate and inappropriate work conduct, which will carry into their offices once they graduate. Unsuitable work behaviour, such as abusing company IT resources, may generate massive losses for the company as it could slow its system network and infect its downloaded virus [6].

Higher education institutions have strict regulations related to the ethical use of their information technologies. However, students generally do not possess the required awareness of information technology's ethical use; consequently, they may decide and act without knowledge about ethical responsibilities and penalties [7]. This type of intellectual property issue triggered by the advancement of the Internet and the propagation of websites reflect improper use of the information they contain regarding ownership rights and intellectual property.

In recent years, we have witnessed an important increase in the illegal use of software and replication of all kinds of intermedia [8]. These actions, which are considered morally wrong, become familiar for students, leading to critical consequences in their professional future. Individuals may have constructive perceptions of ethics, which may be totally in compliance with the value. Individuals who have negative perceptions of ethics are usually identified with various attributes, such as having an executive position, inspiration, principles, and personality [5].

This study inspects the awareness of cyber ethics perception by undergraduate students within a gender-segregated environment, during the covid-19 pandemic. It mainly investigates the extent to which distinct attributes, namely gender, major, grades/ CGPA, and education level, contribute to the perception of students' ethical behaviour. This study's conceptual framework is based on research reviews that identified individuals' attributes that affect computer ethics behaviour. We may cite the work of Ford et al. [9], where various individual attributes were found related to computer ethics attitudes and decision-making processes. Their work was found aligned and relevant with the results obtained by this study.

\section{Literature Review}

Cyber ethics-related issues have generated various research papers around the world. The majority of these works determined the awareness level among undergraduate University students from the opposite gender regarding cyber ethics. A review of these studies is presented in this section.

\section{Students' Awareness and Perception of Cyber Ethics}

Oyewole [10] examined undergraduate students' perception regarding computer ethics in a Nigerian university. The author found out that students have a high level of apprehension on issues related to computer ethics. However, they have low adherence to applying this concept in their studies because of their low income and ineffective punishment measures imposed by the institution.

Various studies have investigated cyber ethics' perception and analysed undergraduate students' awareness in academic institutions in Malaysia [11], in Jordan [12] and in the Philippines [13]. These studies concluded that, in general, students are adequately aware of computer ethics issues.

In their study, Tella and Oyeyemi [14] found out that most undergraduate students have a reasonable awareness of copyright violations in Nigeria. Another study performed by Louw [15] in a higher education institution in South Africa showed that students and staff are aware of the various plagiarism acts enabled by the use of computers, specifically the act of copying from the Internet without mentioning references.

Aliyu et al. [16] have stressed the importance of providing adequate education to students in higher education institutes about cyber ethics to increase their awareness about this sensitive topic, which will give them an understanding of any unethical use of computers in their future professions.

\section{Factors Influencing Computer Ethics}

According to Ford and Richardson [9], individual characteristics influence ethical or unethical behaviour performed by people in their daily activities. 


\section{Gender}

Many researchers have intensively studied the relationship between gender and computer ethics, and mixed results were reported. In their research, Chow and Choi [17] found that people's behaviour related to the ethical viewpoint was independent of gender. Mohamed et al. [18] have also investigated the relationship between gender (students and staff) with computer ethics in a Malaysian University. They found out that ethical computer use is not related to gender. A similar study was also performed by [19], on groups of students in UK/Irish and Malaysian universities to investigate the differences in computer ethics perceptions in a number of ICTrelated cases. For this purpose, the researchers have tested the differences in gender regarding the cultural background. They concluded that the students' ethical perceptions in ICT-related cases differ most significantly based on their social background.

However, other studies found a strong relationship between gender and people's behaviour towards computer ethics and they concluded that male students were found to reproduce software illegally more frequently than female students. Acilar and Yoruk [20] investigated the behaviour of business administration students in the University of Galati in Romania regarding computer ethics. It was found that men were more audacious than women regarding the illegal use of computers. McCarthy et al. [21] concluded that there are significant differences between female and male computer information systems students' ethical beliefs. They proclaimed that reproducing illegally software was an activity performed usually by men rather than women.

\section{Major}

Research work done by North et al. [22] showed the necessity of having cyber ethics awareness. They concluded that education is the only successful way to enhance cyber ethics awareness among these students at the university level; special emphasis on all IT fundamental topics and their related social concerns and problems should be taught early. Aliyu et al. [16] have found similar results. Their study was based on undergraduate students in technology and education majors in Malaysia to measure cyber ethics awareness level. Students enrolled in Technology have dedicated courses in security and ethics as part of their curriculum, while education students do not have any specialized courses related to these topics. The results showed that students in technology majors have statistically better cyber ethics awareness level compared to their counterparts in education major, though both parties have adequate awareness levels.
Jamil et al. [23] studied cyber ethics perception of undergraduate students in information technology and social sciences. Conclusions revealed that students from computing and information technology departments have better awareness than those enrolled in social sciences regarding their behavioural practice with computers and other ICT devices. These results showed that academic majors have a great impact on students' perception of cyber ethics.

\section{Age}

Hasan et al. [24] observed students' perception and awareness in the faculty of accountancy in a University in Malaysia regarding cybercrime. They reported that

(i) students aged 24 years and above had statistically higher awareness rates than those aged between 18 to 23 , and

(ii) students with a good understanding of offenses had better positive perceptions rates of cybercrime.

Gan and Koh [25] also conducted a similar study at Singapore's three universities. Results obtained showed that junior students seemed to illegally copy software more frequently compared to senior students.

\section{Other Factors}

Research conducted by Dorantes et al. [26] found that religious credence impacts ethical behaviour. Kim [27] found that Korean IT professionals with strong religious beliefs have better ethical attitudes than their co-workers who do not. Mohamed et al. [18] investigate how religious work value is related to computer use ethics attitudes. The findings indicated Islamic work ethics are connected to behaviour related to the ethical use of computer.

In their research paper, Ceyhan and Ceyhan [28] stated that unethical behaviours related to the use of IT-related devices might be triggered by different reasons such as social, moral, and economical. More specifically, Rahman and Sultana [29] provided a detailed analysis of why direct undergraduate students commit software piracy acts. Their study was based on undergraduate students in Bangladesh. They have enumerated various attributes mentioned by students, as direct reasons to have unethical behaviour, such as lack of income, poverty), weak law implementation, moral degradation, and lack of awareness of infringement of the law. Oyewole [10] obtained similar results, who found out that the most prominent factors to the low adherence to cyber ethics were 
- the bad economic conditions of the country,

- lack of money,

- penalty measures not being correctly applied, and

- direct influence on students by their peers.

\section{Purpose of the Study}

The objectives of this study were to:

1. Develop a valid tool for determining the level of students' awareness of cyber ethics;

2. Identify attributes that influence student cyber ethics awareness;

3. Evaluate the overall level of students' cyber ethics awareness and the level of students' awareness in each identified attribute; and

4. Explore whether cyber ethics awareness differs when it comes to major, gender, education level, and CGPA.

\section{Significance of the Study}

This study is designed to determine the awareness and challenges of cyber ethics behaviour among university students. It should provide higher management with data about students' awareness of cyber ethics, which will help:

1. Program coordinators in designing the computer ethics course syllabus specifically, and in developing curricula that emphasize the importance of ethical education with regards to computers' appropriate use;

2. Educators in developing adequate workshops for students to teach them about ethical behaviours related to the use of IT-related devices. These workshops should be directed to junior and senior students yearly before their graduation to prepare them for work and prevent eventual cybercrime acts;

3. Administrators in organizing regular and adequate workshops for all academic and non academic staff members to inform them about cyber ethics, prevent cybercrime acts to be committed, and establish an excellent example of classroom ethical behaviours.

The above points provide quality graduates who will show strong ethical values and high levels of competence once employed.

\section{Methodology}

\section{Sample}

This research depends on a self-administrated questionnaire. A survey questionnaire was applied to collect data from a specific group of students in May 2020. A total of 322 undergraduate students at a
University in UAE were found to complete the survey. $164(51 \%)$ of the respondents were female, and $158(49 \%)$ were male students. $172(53.4 \%)$ of the respondents were IT majors, and $150(46.6 \%)$ were non-IT students. 63 (19.5\%) acknowledged themselves to have a CGPA of 3.6 or above and 259 $(80.5 \%)$ with CGPA<3.6. $84(26 \%)$ were in their fourth year, and 238 (74\%) were in their first to third years.

\section{Instrument}

The research instrument consisted of a self-report questionnaire with a two-part structure designed to collect responses. The first section collected demographical/personal data based on five items related to participants' profiles, including gender, CGPA, major, and the number of credit hours completed. The second part assessed respondents' perception toward the ethical use of IT-related devices. It consisted of 21 items on the 5-point Likert scale, ranging from "1-very acceptable" to "5-very unacceptable". These items were mainly based on the survey used by Omosalewa et al. [30].

\section{Reliability}

To determine the internal questionnaire consistency, we have performed a reliability analysis using Cronbach's alpha, once the data collection phase was completed. The satisfaction scale's alpha reliability coefficient was 0.95 , which indicated that the instrument was highly reliable.

\section{Research Model and Hypotheses}

Figure 1. represents the conceptual research model for the study.

The research hypotheses are listed below:

- H1: There is no significant difference in awareness of cyber ethics between male students and female students.

- H2: There is no significant difference in students' awareness of cyber ethics between students with CGPA less than 3.6 and students with CGPA greater than or equal to 3.6.

- H3: There is no significant difference between information technology and non-information technology students' awareness of cyber ethics.

- H4: There is no significant difference in students' awareness of cyber ethics between senior and junior students. 


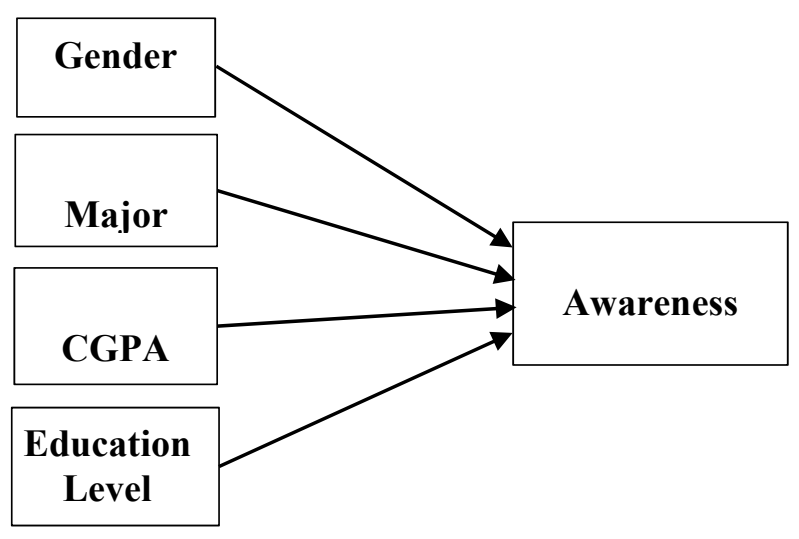

Figure 1. Conceptual Research Model

\section{Level of Cyber ethics Awareness}

The level of students' awareness toward cyber ethics was determined using descriptive statistics that include means and standard deviations. To analyse the results, tabulation of the mean cyber ethics awareness was prepared. Student responses for each item were used to calculate the overall mean score based on the selected scale. Accordingly, cyber ethics awareness levels were interpreted using the following groupings: less than $3=$ low awareness level; between 3 and $4=$ moderate awareness level; greater than or equal $4=$ high awareness level. As shown in Table 1., the mean for overall cyber ethics awareness was 3.43 and a standard deviation of 1.501 for both genders. This result shows that students' awareness of cyber ethics is rated as moderate. This table also illustrates the two-sample t-test comparing male's and female's behaviour regarding various cyber ethics issues. It revealed a significant difference in all 21 questionnaire items between female and male students regarding their awareness of cyber ethics issues. It was found that female students' mean score was greater than male students mean score for all 21 questionnaire items (see Table 1.). Female students display a higher level of cyber ethics awareness than their male counterparts.

\section{Relation Between Individual Characteristic and Cyber ethics Awareness}

\section{Gender}

H1: There is no significant difference in awareness of cyber ethics between female and male students

We have conducted an independent t-test for hypothesis H1, shown in Table 2. The test aimed to determine if female and male students have a different awareness level of cyber ethics. The result shows that there is a statistically important difference in male students' awareness of cyber ethics (Mean=
3.04, Standard Deviation =1.537) and female students' awareness of cyber ethics (Mean $=3.83$, Standard Deviation= 1.343; $\mathrm{t}(320)=-5.160, \mathrm{p}=$ 0.000). Consequently, we reject hypothesis $\mathrm{H} 1$.

In conclusion, this result reveals an important difference in students' awareness of cyber ethics between male and female students. Specifically, female students have a higher awareness of cyber ethics than their male counterparts.

\section{Grades / CGPA}

$\mathrm{H} 2$ : There is no significant difference in students' awareness of cyber ethics between students with $C G P A<3.6$ and students with CGPA $>=3.6$

We have conducted an independent t-test for hypothesis $\mathrm{H} 2$, shown in Table 3 . The test aimed to determine if students with CGPA $\geq 3.6$ and CGPA $<3.6$ have different awareness level of cyber ethics. The result shows that there is no statistically important difference in students awareness of cyber ethics, between students with CGPA $<3.6$, (Mean= 3.32, Standard Deviation $=0.993$ ) and students with CGPA $\geq 3.6$, $($ Mean $=3.44$, Standard Deviation= $1.480 ; \mathrm{t}(320)=2.47, \mathrm{p}=.660)$. Consequently, we accept hypothesis $\mathrm{H} 2$.

In conclusion, this result reveals that there is no significant difference in students' awareness of cyber ethics between students with CGPA $\geq 3.6$ and students with $\mathrm{CGPA}<3$ and that students with CGPA $\geq 3.6$ and CGPA $<3.6$ have similar cyber ethics awareness.

\section{Major}

H3: There is no significant difference between IT and non-IT students' awareness of cyber ethics

We have conducted an independent t-test for hypothesis H3, shown in Table 4. The test aimed to determine if IT students and non-IT students have different awareness level of cyber ethics. The result shows that there is no statistically important difference between IT students' awareness of cyber ethics $($ Mean $=3.5$, Standard Deviation $=1.495)$ and NON-IT students' awareness of cyber ethics (Mean= 3.32, Standard Deviation $=1.146 ; \mathrm{t}(196)=-2.47$, $\mathrm{p}=.016$ ). Consequently, we accept hypothesis H3.

In conclusion, this result reveals no significant difference in students between IT students' awareness of cyber ethics and non-IT students' awareness of cyber ethics.

\section{Education (Senior/ Junior Students) level}

H4: There is no significant difference in students' awareness of cyber ethics between senior students and junior 
We have conducted an independent t-test for the H4 hypothesis, shown in Table 5. The test aimed to determine if senior students and junior students have different awareness levels of cyber ethics. The result shows that there is a statistically important difference between senior students' awareness of cyber ethics (Mean $=3.954$, Standard Deviation $=1.349)$ and junior students' awareness of cyber ethics (Mean= 3.24, Standard Deviation $=1.509 ; \mathrm{t}(320)=-2.47$, $\mathrm{p}=.016$ ). Consequently, we reject hypothesis $\mathrm{H} 4$.

In conclusion, this result means there is a significant difference in students' awareness of cyber ethics between senior and junior students.

\section{Discussion}

As indicated previously, 3.43 is the overall mean value of students' responses on the questionnaire, indicating a moderate level of students' awareness regarding cyber ethics awareness. We recommend implementing the following actions based on the findings of the above section:

1. Develop curricula that emphasize the importance of ethical education with regards to computers' appropriate use in all majors;

2. Organize workshops for students about ethical behaviours in relation to the use of IT-related devices. These workshops should be directed to junior and senior students on a yearly basis before their graduation to prepare them for work environment better and prevent eventual cybercrime acts;

3. Organize regular and adequate workshops for all academic and non-academic staff members in the university to inform them about cyber ethics, prevent cybercrime acts from being committed, and establish an excellent example of classroom ethical behaviours.

\section{Individual Characteristic and Cyber ethics Awareness}

We analysed differences in cyber ethics awareness among students with different demographical/ personal characteristics. The following conclusions were reached:

\section{Gender}

Based on the findings, female students' mean score was greater than male students for all 21 questionnaire items (see Table 2.). These results imply that female students are more likely to make the right cyber-ethical decisions than male students. This conclusion supports the results of earlier performed research works. McCarthy et al. [21] concluded that important differences existed between male and female information systems students' cyberethical beliefs. They proclaimed that reproducing illegally software was an activity performed usually by men rather than women. Acilar and Aydemir [31] also investigated gender differences in the behaviour of 143 freshman business administration students in Turkey regarding computer ethics. It was found that men were more audacious than women regarding illegal use of computers. These studies state the gender influences behaviour concerning IT ethics, particularly among students.

However, other experimental studies performed on non-student populations found no significant difference in terms of gender regarding software piracy, such as Taiwan's case [32] or Sweden [33]. Several other studies indicated that gender does not have a relationship with cyber ethics [18] [32] [33].

\section{Grades}

The study found no significant differences in awareness of cyber ethics between students with CGPA $>=3.6$ and students with $\mathrm{CGPA}<3.6$. Both groups have similar awareness toward cyber ethics. Although the independent t-test analysis shows no statistically significant difference in cyber ethics awareness between the above two groups. However, the mean for students with CGPA greater than or equal to 3.6 is higher by $3.5 \%$.

\section{Major}

The study found no significant differences in awareness of cyber ethics between IT students and non-IT students. Both groups have similar awareness toward cyber ethics. This study's findings supported the results of earlier studies by North [22] and Aliyu et al. [16]. Although, the independent t-test analysis showed no statistically significant difference in cyber ethics awareness between IT non-IT students. However, the mean for information technology students is higher by $5 \%$.

\section{Education (Senior/ Junior students) level}

The study found significant differences in awareness of cyber ethics between fourth-year students and first-year to third-year students. This finding coincides with other studies' results [11] [20].

\section{Conclusion}

Nowadays, the teaching and learning process involves heavily using computers and IT-based resources, which requires reinforcing the awareness of these resources' ethical use among the university students. The ultimate objective is to educate undergraduate students to make use of IT-related 
resources ethically and to develop good virtues that will guarantee principles background for their entire work journey. On the other side, students with low awareness about ethical behaviour will produce negative effects not only during their studies but also on society. It was crucial to explore the awareness of cyber ethics use of IT-related resources in university students related to their learning practices during COVID-19 pandemic.

This research work investigated the extent to which students' personal features are related to cyber ethics awareness. A sample of 322 undergraduate students was selected for this purpose. The results showed important differences between undergraduate information technology students in their ethical beliefs, more specifically, male undergraduate students have a lower ethical behaviour than female students.

Comparing senior (fourth-year students) with junior (first, second, and third-year students), the results showed an important difference between senior undergraduate students and junior undergraduates in cyber ethics awareness. This study had found no significant difference in cyber ethics awareness when it comes to major and grades.

This research has mainly contributed to exploring new knowledge among undergraduate students through the reliable and validated instrument on cyber ethics awareness from a methodology point of view.

Male and female undergraduate students who participated in this study are getting the same education and prepared for similar careers. They still have different cyber ethics awareness. Program coordinators, educators, and administrators should consider these differences while developing curricula, workshops related to ethical behaviour, preparing cyber ethics policies, and professional codes of conduct.

\section{Limitation and Future Work}

There are two noteworthy limitations of this study:

1. This study's participants are mainly undergraduate students, which may not represent the university's general population. It will be a good idea to include postgraduate students in future studies.

2. The sample was selected from one university in the UAE, limiting the generalization of the findings. Including students from other UAE universities would provide better opportunities to understand gender and other individual factors influencing university students' cyber ethics.

Table 1. Awareness of cyber ethics of 322 undergraduate students

\begin{tabular}{|c|c|c|c|c|c|c|c|}
\hline \multicolumn{8}{|c|}{$\begin{array}{c}\text { Rate each of the following items on a scale from } 1 \text { to } 5 \\
\text { (1 being very acceptable; } 2 \text { - acceptable; } 3 \text {-neutral, } 4 \text { - unacceptable, And } 5 \text {-very unacceptable) }\end{array}$} \\
\hline & & \multicolumn{2}{|c|}{ Both Genders } & \multicolumn{2}{|c|}{ Male } & \multicolumn{2}{|c|}{ Female } \\
\hline \# & $\begin{array}{l}\text { ITEM } \\
\end{array}$ & Mean & St. Dev. & Mean & St. Dev. & Mean & St. Dev. \\
\hline 1 & $\begin{array}{l}\text { Providing unauthorized access to other people's personal } \\
\text { information. }\end{array}$ & 4.52 & .724 & 4.25 & 0.790 & 4.77 & 0.546 \\
\hline 2 & Make an unauthorized copy of someone else's work. & 4.37 & .926 & 4.09 & 1.033 & 4.64 & 0.717 \\
\hline 3 & Take credit for someone else's work. & 3.83 & 1.502 & 3.42 & 1.675 & 4.22 & 1.193 \\
\hline 4 & Pay someone to write an essay. & 3.51 & 1.551 & 3.18 & 1.639 & 3.82 & 1.398 \\
\hline 5 & $\begin{array}{l}\text { Copy a project or research from the Internet and submit it as } \\
\text { one's work. }\end{array}$ & 3.42 & 1.624 & 2.97 & 1.659 & 3.84 & 1.473 \\
\hline 6 & Cheat on a graded assignment. & 3.30 & 1.674 & 2.89 & 1.666 & 3.70 & 1.587 \\
\hline 7 & Cheat on an exam. & 3.41 & 1.648 & 2.95 & 1.685 & 3.86 & 1.486 \\
\hline 8 & $\begin{array}{l}\text { Plagiarize other people's work without citing, or referencing the } \\
\text { work. }\end{array}$ & 3.27 & 1.622 & 2.78 & 1.594 & 3.73 & 1.515 \\
\hline 9 & $\begin{array}{l}\text { Add the name of a non-contributing person as an author in a } \\
\text { project or a research study. }\end{array}$ & 3.37 & 1.580 & 2.90 & 1.644 & 3.82 & 1.374 \\
\hline 10 & $\begin{array}{l}\text { Copy and paste material found on the Internet for an assignment } \\
\text { without acknowledging the authors of the material. }\end{array}$ & 3.32 & 1.566 & 2.87 & 1.601 & 3.75 & 1.407 \\
\hline 11 & $\begin{array}{l}\text { Deliberately provide inaccurate references for an assignment, } \\
\text { project, or research study. }\end{array}$ & 3.36 & 1.575 & 2.91 & 1.623 & 3.80 & 1.396 \\
\hline 12 & $\begin{array}{l}\text { Submit another student's assignment, project, or research study } \\
\text { as your work. }\end{array}$ & 3.37 & 1.592 & 2.91 & 1.656 & 3.82 & 1.393 \\
\hline 13 & $\begin{array}{l}\text { Surf the Internet for personal interest and non-class related } \\
\text { purposes during classes. }\end{array}$ & 3.14 & 1.543 & 2.72 & 1.535 & 3.54 & 1.446 \\
\hline 14 & Make a copy of the software for commercial use. & 3.31 & 1.556 & 2.90 & 1.613 & 3.71 & 1.391 \\
\hline 15 & Give a copy of the software for a friend. & 3.14 & 1.547 & 2.70 & 1.541 & 3.56 & 1.437 \\
\hline 16 & Loan software to friends. & 3.12 & 1.523 & 2.75 & 1.535 & 3.49 & 1.425 \\
\hline 17 & Download pirated software. & 3.22 & 1.577 & 2.75 & 1.616 & 3.68 & 1.396 \\
\hline 18 & Distribute pirated software. & 3.30 & 1.555 & 2.84 & 1.588 & 3.75 & 1.385 \\
\hline 19 & $\begin{array}{l}\text { Buy a single-user license software and then install it on multiple } \\
\text { computers. }\end{array}$ & 3.20 & 1.545 & 2.83 & 1.573 & 3.62 & 1.407 \\
\hline 20 & Share a pirated copy of the software. & 3.28 & 1.555 & 2.82 & 1.562 & 3.71 & 1.414 \\
\hline 21 & Install a pirated copy of the software. & 3.24 & 1.545 & 3.64 & 1.422 & 3.64 & 1.422 \\
\hline & MEAN & 3.43 & 1.501 & 3.04 & 1.37 & 3.83 & 1.343 \\
\hline
\end{tabular}


Table 2. Independent Sample t-test Analysis related to students' awareness of cyber ethics with regards to their gender

\begin{tabular}{|c|c|c|c|}
\hline \multicolumn{2}{|l|}{ Category } & \multicolumn{2}{|c|}{ Gender } \\
\hline \multicolumn{2}{|l|}{ St. Type } & Male & Female \\
\hline \multicolumn{2}{|l|}{$\mathrm{N}^{0}$ of Participants } & 158 & 164 \\
\hline \multicolumn{2}{|l|}{ Mean } & 3.04 & 3.83 \\
\hline \multicolumn{2}{|c|}{ Standard Deviation } & 1.537 & 1.343 \\
\hline \multicolumn{2}{|l|}{$\mathrm{t}$} & \multicolumn{2}{|c|}{-5.160} \\
\hline \multicolumn{2}{|l|}{ df } & \multicolumn{2}{|c|}{320} \\
\hline \multicolumn{2}{|l|}{$\mathrm{p}$} & \multicolumn{2}{|c|}{0.000} \\
\hline \multirow{2}{*}{$\begin{array}{c}95 \% \text { Confidence Interval } \\
\text { of the Difference }\end{array}$} & Lower & \multicolumn{2}{|c|}{-1.139} \\
\hline & Upper & \multicolumn{2}{|c|}{-.505} \\
\hline
\end{tabular}

Table 3. Independent Sample t-test Analysis related to students' awareness of cyber ethics with regards to their grades

\begin{tabular}{|c|c|c|c|}
\hline \multicolumn{2}{|l|}{ Category } & \multicolumn{2}{|c|}{ Grades } \\
\hline \multicolumn{2}{|l|}{ St. Type } & CGPA $<3.6$ & $\mathrm{CGPA} \geq 3.6$ \\
\hline \multicolumn{2}{|c|}{$\mathrm{N}^{\mathrm{o}}$ of Participants } & 259 & \begin{tabular}{|l|}
63 \\
\end{tabular} \\
\hline \multicolumn{2}{|c|}{ Mean } & 3.32 & 3.44 \\
\hline \multicolumn{2}{|c|}{ Standard Deviation } & 1.480 & 1.515 \\
\hline \multicolumn{2}{|c|}{$\mathrm{T}$} & \multicolumn{2}{|c|}{0.247} \\
\hline \multicolumn{2}{|l|}{ Df } & \multicolumn{2}{|c|}{320} \\
\hline \multicolumn{2}{|l|}{$\mathrm{P}$} & \multicolumn{2}{|c|}{0.660} \\
\hline \multirow{2}{*}{$\begin{array}{l}95 \% \text { Confidence } \\
\text { Interval of the } \\
\text { Difference }\end{array}$} & Lower & \multicolumn{2}{|c|}{-0.6377} \\
\hline & Upper & \multicolumn{2}{|c|}{-0.62} \\
\hline
\end{tabular}

Table 4. Independent Sample t-test Analysis related to students' awareness of cyber ethics with regards to their major

\begin{tabular}{|c|c|c|c|}
\hline \multirow{2}{*}{\multicolumn{2}{|c|}{$\begin{array}{l}\text { Category } \\
\text { St. Type }\end{array}$}} & \multicolumn{2}{|c|}{ Major } \\
\hline & & IT & Non - IT \\
\hline \multicolumn{2}{|l|}{$\mathrm{N}^{\mathrm{o}}$ of Participants } & 172 & 150 \\
\hline \multicolumn{2}{|l|}{ Mean } & 3.50 & 3.33 \\
\hline \multicolumn{2}{|l|}{ Standard Deviation } & 1.495 & 1.508 \\
\hline \multicolumn{2}{|l|}{$\mathrm{t}$} & \multicolumn{2}{|c|}{1.07} \\
\hline \multicolumn{2}{|l|}{$\mathrm{df}$} & \multicolumn{2}{|c|}{320} \\
\hline \multicolumn{2}{|l|}{$\mathrm{p}$} & \multicolumn{2}{|c|}{0.314} \\
\hline \multirow{2}{*}{$\begin{array}{l}95 \% \text { Confidence Interval } \\
\text { of the Difference }\end{array}$} & Lower & \multicolumn{2}{|c|}{-0.149} \\
\hline & Upper & \multicolumn{2}{|c|}{0.510} \\
\hline
\end{tabular}

Table 5. Independent Sample t-test Analysis related to students' awareness of cyber ethics with regards to their education level

\begin{tabular}{|c|c|c|c|}
\hline \multicolumn{2}{|l|}{ Category } & \multicolumn{2}{|c|}{ Education Level } \\
\hline \multicolumn{2}{|l|}{ St. Type } & Senior & Junior \\
\hline \multicolumn{2}{|c|}{$\mathrm{N}^{0}$ of Participants } & 84 & 238 \\
\hline \multicolumn{2}{|c|}{ Mean } & 3.954 & 3.24 \\
\hline \multicolumn{2}{|c|}{ Standard Deviation } & 1.349 & 1.509 \\
\hline \multicolumn{2}{|c|}{$\mathrm{t}$} & \multicolumn{2}{|c|}{-3.751} \\
\hline \multicolumn{2}{|l|}{ df } & \multicolumn{2}{|c|}{320} \\
\hline \multicolumn{2}{|l|}{$\mathrm{p}$} & \multicolumn{2}{|c|}{0.003} \\
\hline \multirow{2}{*}{$\begin{array}{l}95 \% \text { Confidence } \\
\text { Interval of the } \\
\text { Difference } \\
\end{array}$} & Lower & \multicolumn{2}{|c|}{-1.079} \\
\hline & Upper & \multicolumn{2}{|c|}{-0.345} \\
\hline
\end{tabular}

\section{References}

[1]. Jamil, M., \& Shah, J. H. (2014). Perception of undergraduates about computer and Internet ethics in Pakistan. Nigerian Journal of Technology, 33(4), 512522.

[2]. Heron, T. W., Cavico, F., Mujtaba, B. G., \& Pellet, P. F. (2007). Ethics and information technology professionals: an examination of gender, age, career stage, education level and ethics training variables. In Proceedings of the EABR (Business) \& ETLC (Teaching) Conference (pp. 1-13).

[3]. Brey, P. (2008). Do we have moral duties towards information objects?. Ethics and Information Technology, 10(2-3), 109-114.

[4]. Al-A'ali, M. (2008). Computer ethics for the computer professional from an Islamic point of view. Journal of Information, Communication and Ethics in Society, 6(1), 28-45.

[5]. Foltz, C. B., Schwager, P. H., \& Anderson, J. E. (2008). Why users (fail to) read computer usage policies. Industrial Management \& Data Systems, 108(6), 701.

[6]. King, D. L., \& Case, C. J. (2007). E-cheating: are students misusing it. Issues in Information Systems, 8(1), 71-75.

[7]. Aderibigbe, N. A. (2020). Cyber ethical behaviour of university students: An overview of university of Zululand, South Africa and Federal university of agriculture, Abeokuta, Ogun state, Nigeria. Journal of Applied Informafion Science and Technology, 13(1), 86-106.

[8]. Cummings, A. S. (2017). Democracy of sound: Music piracy and the remaking of American copyright in the twentieth century. Oxford University Press.

[9]. Ford, R. C., \& Richardson, W. D. (1994). Ethical decision making: A review of the empirical literature. Journal of business ethics, 13(3), 205-221.

[10]. Oyewole, O. (2017). Awareness and Perception of Computer Ethics by Undergraduates of a Nigerian University. Journal of Information Science Theory and Practice, 5(4), 68-80.

[11]. Masrom, M., Ismail, Z. \& Hussein, R. (2008). Computer Ethics Awareness Among Undergraduate Students in Malaysian Higher Education Institutions. Paper presented in 19th Australasian Conference on Information Systems, December, 3-5. Christchurch, New Zealand.

[12]. Ilyadat, W., Iyadat, Y., Ashour, R., \& Khasawneh, S. (2012). University Students and Ethics of Computer Technology Usage: human resource development. Elearning and Digital Media, 9(1), 43-49.

[13]. Verecio, R. L. (2016). Computer ethics awareness: Implication to responsible computing. International Journal of Education and Research, 4(3), 195-204.

[14]. Tella, A., \& Oyeyemi, F. (2017). Undergraduate students' knowledge of copyright infringement. Brazilian Journal of Information Science, 11(2), 38-53.

[15]. Louw, H. (2017). Defining plagiarism: Student and staff perceptions of a grey concept. South African Journal of higher education, 31(5), 116-135. 
[16]. Aliyu, M., Abdallah, N. A., Lasisi, N. A., Diyar, D., \& Zeki, A. M. (2010, December). Computer security and ethics awareness among IIUM students: An empirical study. In Proceeding of the 3rd International Conference on Information and Communication Technology for the Moslem World (ICT4M) 2010 (pp. A52-A56). IEEE.

[17]. Chow, W., \& Choi, K. (2003). Identifying managers who need ethics training in using IT at work. Behaviour \& Information Technology, 22(2), 117-125.

[18]. Mohamed, N., Karim, N. S. A., \& Hussein, R. (2012). Computer use ethics among university students and staffs: The influence of gender, religious work value and organizational level. Campus-Wide Information Systems, 29(5), 328-343.

[19]. Hay, D., Larres, P. M., Oyelere, P., \& Fisher, A. (2001). The ethical perception of undergraduate students in computer-related situations: An analysis of the effects of culture, gender and prior education. Teaching Business Ethics, 5(3), 331-356.

[20]. Acilar, A., \& Yoruk, D. (2010). Gender Differences in Computer Ethics among Business Administration Students. Economics and Applied Informatics, (2), 514.

[21]. McCarthy, R. V., Halawi, L., \& Aronson, J. E. (2005). Information technology ethics: a research framework. Issues in Information Systems, 6(2), 64.

[22]. North, M. M., George, R., \& North, S. M. (2007, March). A brief study of information security and ethics awareness as an imperative component of management information systems. In Proceedings of the 45th annual southeast regional conference (pp. 515-516).

[23]. Jamil, M., Shah, J. H., \& Tariq, R. (2013). IT ethics: Undergraduates' perception based on their awareness'. Journal of Educafion and Pracfice, 4(12), 110-122.

[24]. Hasan, M. S., Rahman, R. A., Abdillah, S. F. H. B. T., \& Omar, N. (2015). Perception and awareness of young internet users towards cybercrime: Evidence from Malaysia. Journal of Social Sciences, 11(4), 395.
[25]. Gan, L. L., \& Koh, H. C. (2006). An empirical study of software piracy among tertiary institutions in Singapore. Information \& Management, 43(5), 640649.

[26]. Dorantes, C. A., Hewitt, B., \& Goles, T. (2006, January). Ethical decision-making in an IT context: The roles of personal moral philosophies and moral intensity. In Proceedings of the 39th Annual Hawaii International Conference on System Sciences (HICSS'06) (Vol. 8, pp. 206c-206c). IEEE.

[27]. KIM, K. H. (2003). A study of the conduct of Korean IT participants in ethical decision making. Lecture notes in computer science, 64-74.

[28]. Ceyhan, A. A., \& Ceyhan, E. (2007). The Relationships among Unethical Computer Usage Behavior and Some Personality Characteristics of Turkish University Students. International Educational Technology (IETC) Conference (7th, Nicosia, May 3-5.

[29]. Rahman, M. A., \& Sultana, S. (2015). Software piracy in Bangladesh: The student perceptions study on two selected public universities in Dhaka City. Manarat International University Studies, 4(1), 148-157.

[30]. O. Aderonmu, C. L. Aasheim, and P. Rutner, "Development and Testing of a Survey Instrument to Assess Ethical Perceptions of IT and IS Students," in Proc. of SEINFORMS'13, 2013, pp. 217-241.

[31]. Acılar, A., \& Aydemir, M. (2009, June). Freshman Students' Attitudes Toward Issues of Computer Ethics. In First International Symposium on Sustainable Development, 2009, Education Proceedings (Vol. 2, pp. 213-222).

[32]. Kuo, F. Y., Lin, C. S., \& Hsu, M. H. (2007). Assessing gender differences in computer professionals' self-regulatory efficacy concerning information privacy practices. Journal of business ethics, 73(2), 145-160.

[33]. Bergström, A. (2015). Online privacy concerns: A broad approach to understanding the concerns of different groups for different uses. Computers in Human Behavior, 53, 419-426. 